\title{
Investigating the Custody in Shiite Jurisprudence and Civil Rights in France
}

\author{
Mahdi Nazemi ${ }^{1} \&$ Abbas Ali Salehi ${ }^{2}$ \\ ${ }^{1}$ University of Meymeh, Iran \\ ${ }^{2}$ Shahrekord University, Iran \\ Correspondence: Mahdi Nazemi, University of Meymeh, Iran. E-mail: parsk67@yahoo.com
}

Received: May 15, 2016 Accepted: June 15, 2016 Online Published: August 30, 2016

doi:10.5539/jpl.v9n7p230

URL: http://dx.doi.org/10.5539/jpl.v9n7p230

\begin{abstract}
Custody in Islam is the procedure for child rearing, which effects his physical and material context. What kept custody of the child apart from other issues, is attention to the spiritual dimension of the child and considering the child needs. Child custody and disputes on it leads to be an important issue for parents in countries civil law. In civil rights it becomes as well as the important of religious orders and opinions of jurists, in this regard recommendations are provided on how to improve the supervision and laws of our country's children for a better life. Therefore, in this case, it is needed to examine the legal opinion regarding to the custody of the two legal systems of Iran and France. The first custody must be investigated and have priority to the custody of the father or mother. In Iranian Civil Code the right and duty of parents in custody knows some right and some homework. In French Civil Code custody of parents towards children in all areas of life for the growth, maintenance and education of children is common and conspicuous aspects of its obligatory. The exercise of the custody right is shared between parents and conditions are considered the parent with custody situations where their absence is excused. Parents under certain circumstances can have the right to self-disclaimer or leave to a third party to ask the court about the right.
\end{abstract}

Keywords: custody, law, maintenance, child, duty

\section{Introduction}

After divorce between the men and women and while they have a child, usually one of the first differences that arise between them is regarding to the custody of their children. Given that my field on family law I'm interested in writing this article is subject to custody dedicated and in the Shiite jurisprudence and civil rights in Iran and France would work. The importance of the education of the child on the one hand and neglect some of the people on the other hand, has made the Imams (AS) in the upbringing of children, people pay more attention to this aspect that many traditions have said about them. In the matter of religious leaders from these traditions that come to us, attention to the education of the child, according to the psychological and spiritual, physical and material issues has been mentioned widely. For this reason, that conditions for child care can be divided into two categories: one category when the spiritual dimension intends child and the need to provide them in the head, because that child will provide spiritual growth, such as: Islam and the moral authority of the latter, children's physical and mental conditions for materials processing, such as wisdom, power, and no dangerous infectious diseases. Various lawyers in custody have had differences opinions so that some conditions have considered that some other countries have not accepted the conditions mentioned, thus, the issue of Iran and France in two legal systems are investigated and reviewed in this paper.

\section{Explain Concepts}

\subsection{Custody in the Word and the Term}

Custody is an Arabic word that entered into the legal literature and consequently into our law books. This Arabic word literally means "keep off, maintain children and foster children". (Ibn Fars, 1404.2: 73). Some researchers philology, custody, in Spanish, the infinitive of the verb Triad single "Hozn Yahzen" means wet nurse the child, child care, education, the education of the child, the skirt defines a minor and child custody. (Hosseini Dashti 4, 2000: 574). In addition in the term is meant to keep (Najafi, 1404, 31: 248). Some meant custody to literally (Khansari, 1405, 4: 472). Some jurist's custody means: "custody, guardianship and reign on children's 
education" (Helli, 1413, 3: 101). Others meant custody, guardianship of children and the insane know that to train and what is expedient done maintaining a woman they like to do more worthy of man and its more emotion or ethics which is suitable for women in these matters "(Shahid Thani, Masalek Alafham, 1416, 8: 421).

Sahib Javaher in the definition of custody, follows Shahid Thani and said: "Reign of custody and guardianship of the child's upbringing and what belongs to his education, such as maintaining him, put him in his bed (Najafi, 1404, 31: 283).

\subsection{The Use of the Custody Word in the Quran}

Quran to express the concept of guardianship and custody, has used the term 'bail'. In a verse about the supervision of Maryam (PBUH), says:

First verse: (Al-Imran, 44). "And you, when your pen (to draw), cast into the water to which a bail Maryam, to be represented ..."

The second verse (Ibid, Verse 37): "God in an appropriate way (although seedlings), Zakaria gave him grow and bail him ..."

In two other verses, custody and maintenance of Prophet Moses (peace be upon him) said:

Third: (Surah Taha, verse 40) "Are you one way I hold him and his nurse ..."

Fourth: (Surah Qasas, verse 12) "So (Moses' sister), said:" Will you accept a family of tips that led him to you "..."

\subsection{Custody in the Traditions}

In this section custody in the narrative traditions of the Infallible Imams (AS) regarding to the custody is sufficient to keep it short into a narrative". David Benhassain narrated from Imam Sadiq (AS) said about the verse of the Qur'an (Baqara, verse 233) (Horamly, 1416, 21, 470 and 471). "And mothers are breastfeeding their children, as long as the infant is, the maintenance of both spouses equally and when he opened the valve, the mother of his father custody and maintenance. If the father dies, the mother of all former foster care family father and if the father of four scrambled to find someone who suckles her mother and tell her I will not give milk to less than five dirhams, parents can take the child from the mother and her nanny, though the child is better and more worthy to be his mother. "

\section{Conditions of Custody in View of Jurisprudence}

Custody for parents, with what proved to be like some of them wisdom and strength, such as its conditions and some like non-married mothers, such as barriers to it. Religious books also have learned these things sometimes hinder and sometimes bet. For example, some jurists consider marriage as a barrier for custody of mother and some have custody, provided contradictory it and said: "the condition of the mother, it is not marriage after divorce" (Bohrani, 25: 90). Or some madness is seen as obstacle custody and others, wisdom, have custody of the condition (Shahid Thani, Masalek Alafham, 1416, 8: 422) by having each of these cases the custody lapses of parent.

\subsection{Common Conditions among Parents}

\subsubsection{Wisdom and Power}

Wisdom and power are two things that human beings worthy of the responsibility. Islam maturity and wisdom of the general conditions assignments and for this reason, lunatics and without disabilities that have wisdom and strength obligation is not burdened (Safai, and Ghasem Zadeh, 1989: 247).

It should be noted that at the beginning of rights, there are two types of competence, Firstly it is a qualifications enjoyment. The second benefit of the right and competencies advocated meant to run right. What is the basis of qualifications and competence for the enjoyment of the rights and benefits is humanity. There once was a man, even if you are not born, possess the ability to acquire and can have rights, but implementation and enforce the right of eligibility criteria, understand and distinguish it (Iraq, 1408: 180 and 181) than obsolete such as children and people with weak or impaired due to dementia do not have the will power and decision-making. The rights and advantages, the capacity to have the first meaning, though not merit its implementation, that is not advocated qualifications and their legal representative is advocated on behalf of these rights.

So, " custody for that kind of shifty and guardianship, and also because it is the right and duty, for one proved to be the reason and have enough power to do so, in addition to the lunatics and persons with disabilities in need of his care (Shahid Thani, Masalek Alafham, 8: 422) if a parent with dementia and cannot have children administration and policy. Not only do not deserve to enforce the right but also will have the capacity to enjoy it. 
Most scholars who have studied the conditions of custody, also according to the wisdom conditioning and have reiterated the need for it (Helli, the rules of Ahkam, 3: 141 and Shahid Thani, Masalek Alafham, 8, 1416, 423 and Amelli Almram, 1: 470 and Momen: 193 and Fazel Hindi, 7: 551. Joseph, Bohrani 25: 91).

Sahib Javaher in this regard writes: "madness is permanent, however, does not invalidate custody, and although children affairs transferred to the inability insane, chief among them is like other affairs insane people in charge. Therefore, the madness enjoyment does not diminish its capacity as such, custody remains for him, but capacity is not advocated, but he will demand it "(Najafi, 1404, 31: 287).

\subsubsection{Islam}

In Islamic law, children before puberty, between Islam and blasphemy follows parent. So, if parents are Muslims, if both Muslim and infidel children in the sentence, the child will be to blasphemy. But if one of the parents is Muslim and the other unbelievers, in this case, the child will be the subject of parent's religion and religion of Islam (Superior), the child will be the religion of Islam. (Aroosi Alhoizi, 4: 211 and Mohaghegh Korki, 12: 395, Shahid Thani, Masalek Alafham, 13: 29).

Based on what was said, when one of the parents is Muslim and the other unbelievers, a child who is born of them, will be sentenced to Islam. On the other hand, transferred custody of a child and child custody authority and domination Muslim infidel "parent", he needs to dominate a Muslim, while the verse of the Qur'an, the unbelievers did not rule on Muslim. Hence, the infidel does not have the right to maintenance and custody of the child and custody of their Muslim he would be a father or mother. (Ibn Babawayh, 4: 334). After the pagan religion of Muslims to the dignity, honor and excellence, and so custody is a kind superiority over angry, the unbeliever does not have custody and the condition, almost unanimously Shiite Fqhan (Tosi, 6, 24 and Amelli Nihayat Almaram, 1413, 1: 469 and Helli, Rules Ahkam, 1413, 2: 201).

Jurists cite this verse to deny that pagan influences in training their children to temper his character, because the child's guardian only maintenance and development of the body are not alone whereas he also is the pattern of behavior. After infidel supervision, grounds for deviating child should be avoided. As a result, the infidel Muslims does not deserve custody of the child "(Shahid Thani, Masalek Alafham, 1416, 8: 422 and Najafi, 1404, 31: 287). The Quran says: "Those who claim to believe in God are more, are polytheists" (Yusuf, verse 106). Therefore, if it is, the criterion of true faith is odd child care; more people will have to sustenance children, in addition to knowing the true faith no way, other than to cite the apparent criteria.

\subsubsection{Moral Authority}

Islam, culture and moral education of children concentrate the attention into the same direction, order a lot about the moral education of children care. Parent organized crime and corruption with moral, spiritual and ethical dimension of their ignorant, so will not be able to act in moral education of their children properly, so how can they expect their children to obey the religious orders, customs, moral guidance and discipline?

\subsubsection{Justice}

Jurists condition of justice in child care have different interpretations which is expressed in the words of the jurisprudents; some have interpreted it in truth and righteousness and have raised some of debauchery. The purpose of justice in terms of righteousness, the faithful and non-debauchery in a word can be interpreted as a moral authority. About justice, there are two major approaches. More jurists as the owners of documents, have accepted it and justify it cited the following reasons:

1) Custody rebellious province and no province.

2) Evil and fear that it is not trusted to betray children.

3) Unfaithful interest of the child, because the child is trained in their own way (Tosi, 2008, 6: 40 and Shahid Thani 8: 424). Some jurists have not provided justice. (Helly, 1413, 3: 101 and Bohrani, 1409, 25: 92) It is obvious that parents are morally corrupt, can never be effective in moral education of their child and if the child is in their possession, they will be trained in accordance with the ethics and the highest losses for the child, because the field of happiness is compromised.

\subsubsection{Lack of Dangerous Infectious Diseases}

Maintenance of the children and keep body and soul of his diseases and risks. If a parent or both infectious and incurable diseases or incurable affected and ensure that children with them, he also is at the risk of infection, is custody for these parents fixed? The verse refers (Kleene, 1996, 5: 294). We can say that these people do not deserve to custody and most patients with these diseases with the remaining in their own affairs are in need of supervision. So naturally stop the child's ability to govern. Therefore, the detainees for two reasons, conditions 
do not have the right to custody. Since the exposure of children to these people, child physical health is at risk and that verse it is rejected because it did not have enough to do this (Shahid Thani, Masalek Alafham, 1416, 8: 422).

\subsection{Mother's Special Condition (Not Married to the Mother)}

According to some traditions, a special condition for custody of their mothers and, mother custody, subject to no other than the child's father is married to his wife. If she divorced her husband and the woman and the child until the child is more competent on maintenance marry, but if in the meantime other than the child's father married spouses, custody, he will fail. In this case there is a tradition that should be addressed to Imam Sadiq (AS) "about a man who divorced his wife while the two children, was asked what are right? Imam (AS) said: Woman has the custody right to children, while not married again. "(Kleene, Kafi, 6: 45) Many scholars have mentioned the condition of marriage was a condition of the mother (Ibn Babawayh, 1996, 3: 435) Shahid Thani on its conditioning, believes to the consensus. (Shahid Thani, Alrozeh Albahieh, 1416, 5: 463). Also some jurists, in addition to citing the hadiths mentioned, have made statements to justify this requirement, Fazel Hindi said: "Marriage requires that sexual woman, the husband is at all times. This requires that women of child fail completely to deal with it "(Fazel Hindi, 1416, 7: 551).

\section{The Custody Conditions in the French Civil Rights}

In French law, the custody under the custody of the father and mother, "the provincial parent" of the child is defined in the French Civil Code reads: children of all ages should honor their parents and be proud of him (Article 371).

Custodial parent, a set of rights and obligations they have a duty to protect the children about safety and their health until they show maturity (Article 371 paragraph 1).

Each of the parents, for the cost of child care for your child's education than their status and the child is responsible and this obligation continues until the child's development (Article 371, paragraph 2). The French Civil Code is announced with concerning women and men who are not married and have children with a court order to create the conditions for legal custody of the parent for the child. Name and Surname in French law when the parents on the child's birth certificate is recorded, automatically applied to the child's custodial parent.

But what about couples who have kids before marriage becomes official when the custody applies the father are known and during a year living with the child's mother must be legally sign a joint statement. "Marriage" under Article 372 of the Civil Code of France this regard by the courts declared to be a legal relationship and in case of disagreement between parents that should give a request to the Family Court to the Court of Justice concerning and joint custody of the child's parents announce.

Request for custody of parents within the jurisdiction of the family court according to the rules laid down in references and the provisions of this section up and checked (article 1179 of the French Civil Code) Joint custody parents (Article 372 German Civil Code).

However, when the relationship between parent and child is created in a year after the birth of the child, the parents' relationship is formed and will only delegated custody of the continuing relationship between father and son and parents in the second stage of a relationship with the judiciary. From the custody insight, if the parent is deprived of government regulations express their common. Due to absence of law and lack of capable in any other cause (Article 373 German Civil Code). The French Civil Code states that the conditions for custody of the child. Custody, denies parents (Article 378 paragraph 1 of the French Civil Code).

1) Any criminal conviction.

2) The abuse of children.

3) Excessive use of alcoholic beverages.

4) Drug use.

5) Any criminal behavior towards children.

6) Endangering the health and morals of children.

Lack of waiver of custody

French civil law can give parents' custody of the child to another or to third party. Parents or separately can apply in terms of the need to delegate all or part of the actions of their custody to the other parent or a trusted relative or to get social assistance and services to the court's childhood (Article 377 of the French Civil Code Part One). 


\section{Conclusion}

We conclude from this discussion, custody Arabic word that the legal literature and consequently into our law books. In Arabic, the word means to preserve, foster child is getting along. Refers to Shiite scholars to define those who have custody, is the first of Allameh Helli said: "Custody and Guardianship reign on children's education". Shahid Thani also says: "custody of children and the insane is to train and what his interests". Muhammad Jawad Mughniyah has defined custody as: marriage, child custody and property have nothing to do with the province.

Several verses in the Quran about the custody are referred such as: the Quran expresses the concept of guardianship and custody, by entitling it bail term (Surah Imran, Verse 44) and by words of the Prophet and the Infallible Imams, our traditions are in custody.

Custody of Jurisprudence conditions were as follows:

Common conditions: 1 - wisdom and power 2 - Islam 3 - moral authorities 4 . Justice 5 dangerous infectious diseases 6- conditions of married mothers

The French Civil Code states that the conditions for custody of the child. Custody, denies parents (Article 378 paragraph 1 of the French Civil Code) in the following conditions:

1) Any criminal conviction.

2) The abuse of children.

3) Excessive use of alcoholic beverages.

4) Drug use.

5) Any criminal behavior towards children.

6) Endangering the health and morals of children.

French parent's civil law can give custody of the child to another or to third person.

\section{References}

Abn Manzor, Muhammad, Arab language, vol 13, no 1, Beirut Darlahya' Altras Arabi, Beirut, $1374 \mathrm{n}$.

Ahmad, Ibn Fars, Alghh, Vol. 2, Ch 1, Qom Islamic Publications Office, 1404 AH.

Allameh Helli, Hassan ibn Yusuf, different Shi'a, vol. 5, no 2, of the spread of Islam in Qom, 1413 AH.

Almhqq Alnaraqy, Ahmad, Avayed-Ayyam, China 2, Albsyrty school Qom, 1408 AH.

Altarihi, Sheikh Alfkhr al-Din al Assembly, vol. 6, no. 3, Mortazavi, Tehran Publishing, $1996 \mathrm{n}$.

Amelli, Mohammad Ibn Ali, Almram, vol. 1, no 1, Institute spread Islam in Qom, 1413 AH.

Aroosi Alhoizi, Abdul Ali, Tafsir Noor Al-Thaqalayn, Vol 4, No 4, the Institute of Ismaili Qom, 1994 n.

Bohrani, Joseph, Hadaegh Alnazrh, vol 25, no 1, Institute spread Islam in Qom, 1409 AH.

Chiellini Mohammed, Kafi, vol. 5, no 3, examples Qom Publishing, 1996 n.

Fazel Hindi, Mohammad, discovered Allsam Valaabham as rules Ahkam, vol. 7, no 1, Institute spread Islam in Qom, $1416 \mathrm{AH}$.

Horamly, Mohammed, Wasael, vol 21, no 3, Al al-Bayt (AS), Qom, Sha'ban 1416 AH.

Hosseini, Dashti, Mostafa, education and standard, vol. 4, no 3, Tehran provider, $2000 \mathrm{n}$.

Ibn Babawayh (Sheikh Saduq), Muhammad, Layhzrh al-Faqih, vol. 4, No 1, correction Joseph Bekaa, Daralazva', 1413 BC.

Ibn Idris, Mohammad, Alsarair, Vol. 2, No 2, the release of al-Islami Institute, Qom, $1410 \mathrm{AH}$.

Ibn Yusuf, Hilli, Hassan, Ahkam rules, vol. 3, No 1, of the spread of Islam in Qom, $1413 \mathrm{AH}$.

Jabali Amelli (Shahid Thani), Zinedine Masalek Alafham, vol 13, no 1, Institute of Islamic Encyclopedia, 1416 $\mathrm{AH}$.

Katuzian, N, civil rights, family, Vol. 2, No 3, Tehran, Publishing Company, 1993 n.

khansari, Sayed Ahmad, a comprehensive Almdark fi Brief Description Alnaf, vol. 4, no 2, Esmaillids Institute, 1405 BC.

Korki, Ali ibn Hussein, a comprehensive Almqasd, vol 12, no 2, Institute of al-Bayt (AS) in Qom, 1414 AH. 
Moeen, Mohammed, Persian Culture, vol. 1, no 8, Amir Kabir Publications, Tehran, 1992 Sh.

Momen (Sabzevari), Mohammad Bagher, Kifaya Ahkam, China 1, the Office of Qom Seminary basin in 1423 BC.

Mughniyeh, Mohammad Javad jurisprudence of Imam Ja'far al-Sadiq (AS), no one, 'House, Beirut, 1966 AD.

Muhammad, Ibn Babawayh (Sheikh Saduq), I Layhzrh al-Faqih, vol. 3, No 2, of the spread of Islam in Qom, $1413 \mathrm{AH}$.

Muhammad, Ibn Babawayh (Sheikh Saduq), Layhzrh al-Faqih, vol. 4, no 2, of the spread of Islam in Qom, 1413 $\mathrm{AH}$.

Najafi, Sheikh Mohammad Hassan, Javaher Kalam, vol 31, no 7, Beirut, Darahya' TURATH, 1404 AH.

Quran.

Safai, Hossein Morteza, Ghasemzadeh, civil rights, China 14, the Ministry of Culture and Islamic Guidance, $1378 \mathrm{n}$.

Sayah, Ahmed, a comprehensive new culture, vol. 1, no 3, Tehran Islam, 1380.

Tusi (Shaykh Tusi), Mohammed Ibn Hassan, Almbsvt, vol. 6, no. 3, Tehran, Iran, in 2008 BC.

\section{Copyrights}

Copyright for this article is retained by the author(s), with first publication rights granted to the journal.

This is an open-access article distributed under the terms and conditions of the Creative Commons Attribution license (http://creativecommons.org/licenses/by/4.0/). 